\title{
PENGEMBANGAN SELF ESTEEM SISWA SMKN 31 JAKARTA SEBAGAI UPAYA MEMPERSIAPKAN DIRI MEMASUKI DUNIA KERJA
}

\author{
Alabanyo Brebahama \\ alabanyo.brebahama@yarsi.ac.id \\ Fakultas Psikologi, Universitas YARSI \\ Sari Zakiah Akmal \\ sari.zakiah@yarsi.ac.id \\ Fakultas Psikologi Universitas YARSI \\ Rina Rahmatika \\ Fakultas Psikologi Universitas YARSI \\ Octaviani I. Ranakusuma \\ Fakultas Psikologi Universitas YARSI
}

\begin{abstract}
ABSTRAK
Remaja merupakan tahapan perkembangan transisi dari masa kanak-kanak menuju masa dewasa. Salah satu tugas perkembangan yang harus dipenuhi oleh remaja adalah mencapai ego identity, yakni memiliki pandangan yang jelas terhadap berbagai aspek dalam dirinya, serta mampu menerima segala kelebihan dan kekurangan dalam dirinya tersebut. Untuk mencapai ego identity tersebut, remaja perlu memiliki konsep diri (self-concept) yang jelas, serta harga diri (self-esteem) yang positif. Hanya saja, hal tersebut tidaklah mudah karena justru remaja seringkali mendapatkan pengaruh negatif dari lingkungan sekitarnya, baik itu orangtua, guru, teman sebaya, hingga media massa. Keharusan untuk mendapat nilai terbaik, pengakuan guru yang terbatas hanya pada siswa berprestasi, tuntutan untuk "gaul" ala remaja, hingga naskah sosial di media massa seringkali justru remaja sulit memiliki penghargaan positif terhadap dirinya, dan melupakan potensi yang sebetulnya ada dalam dirinya. Program pengembangan harga diri (self-esteem) merupakan salah satu bentuk upaya yang perlu dilakukan bagi remaja, terutama oleh sekolah. Namun sayangnya, tidak semua sekolah memiliki sumber daya yang memadai untuk melakukan hal tersebut, seperti SMK Negeri 31 yang berlokasi di Cempaka Putih, Jakarta Pusat. Oleh karena itu, program pengabdian masyarakat ini ditujukan untuk membantu siswa SMK Negeri 31 agar dapat memiliki penghargaan yang lebih positif terhadap dirinya, serta menelaah dan mengembangkan potensi dirinya. Hasil evaluasi efektivitas kegiatan menunjukkan bahwa pelatihan yang dilakukan tidak efektif dalam meningkatkan self esteem siswa. Akan tetapi, secara umum kegiatan yang dilakukan mendapatkan penilaian positif dari peserta.
\end{abstract}

Kata kunci: pelatihan self-efficacy; siswa SMK 


\section{PENDAHULUAN}

Remaja merupakan tahap perkembangan transisi dari masa anak-anak menuju kedewasaan yang berlangsung sejak usia 10 atau 11 tahun sampai usia belasan akhir atau awal usia 20 tahun, serta ditandai dengan adanya perubahan dalam hal fisik, kognitif, dan psikososial (Papalia, Olds, \& Feldmen, 2007). Dengan berbagai perubahan fisik, kognitif, dan sosial emosional yang dialami tersebut, muncul beberapa pertanyaan penting yang harus dijawab oleh remaja sebagai proses pembentukan identitas dirinya (Carr-Gregger dan Shale, 2003). Pertanyaanpertanyaan tersebut meluputi “Apakah saya normal?”(Am I Normal?), "Siapakah saya?" (Who Am I?), dan "dimanakah tempat dan peranan yang tepat bagi saya di masyarakat?" (Where is My Place in the World?). Ketiga pertanyaan tersebutlah yang akhirnya mengantarkan remaja untuk memenuhi salah satu tugas perkembangannya, yakni mencapai ego identity yang jelas, dimana Erikson (dalam Papalia, Olds, dan Feldman, 2007) menyebutnya sebagai tugas perkembangan Identity versus Identity Confusion.

Proses pembentukan identitas diri itu sendiri tidak dapat dipisahkan dengan sejauh mana pemahaman remaja mengenai dirinya sendiri (konsep diri), serta bagaimana penilaian remaja itu sendiri terhadap dirinya, atau disebut juga harga diri (Sulistiyowati dan Warsito, 2010). Remaja yang mempunyai pengetahuan mengenai apsek yang ada dalam dirinya, serta memiliki penilaian akurat terhadap dirinya tersebut cenderung tumbuh menjadi individu dengan harga diri yang tinggi. Hal tersebut dikarenakan remaja mampu memahami realitas yang ada pada dirinya, berupa kelebihan (strength) dan kekurangan (weakness), serta memiliki pandangan bahwa setiap individu adalah unik. Hanya saja, fenomena di lapangan seringkali justru menghambat proses pencarian identitas tersebut. Orangtua, guru, teman sebaya, maupun masyarakat secara umum seringkali justru menimbulkan hal yang sebaliknya, yakni mengantarkan remaja pada harga diri yang rendah (low self esteem). Sebagai contoh, penerapan ranking di setiap kelas, perilaku membandingkan antara siswa yang satu dengan yang lain dalam hal prestasi akademik di sekolah ternyata membuat siswa yang "biasa-biasa saja" justru merasa dirinya tidak kompeten (Santrock, 2007). Contoh lain, penerapan istilah "anak 
gaul" bagi remaja yang berpenampilan maupun berperilaku tertentu menyebabkan sebagian remaja lain dianggap "culun" atau "tidak gaul".

Berdasarkan pengalaman tim pengusul sebagai Psikolog di beberapa sekolah di Jakarta, tidak jarang status sosial dan ekonomi keluarga berdampak terhadap pembentukan harga diri siswa. Misalnya saja: siswa yang berasal dari keluarga menengah ke bawah cenderung merasa "minder" ketika siswa lain memiliki uang saku yang lebih besar, sehingga mampu membeli makanan yang lebih mahal. Adapula siswa yang merasa "rendah diri" ketika siswa lain membicarakan pengalaman liburannya ke luar negeri, ataupun membahas tentang hobi yang membutuhkan sumber daya keuangan (seperti: jalan-jalan ke Mall sambal menonton film di bioskop maupun makan di restoran mahal, melakukan modifikasi kendaraan bermotor, dan sebagainya), sementara ia hanya mampu mengisi waktu luang dengan membantu orangtua. Walaupun terlihat sederhana, ternyata hal-hal tersebut justru dapat memenuhi pikiran siswa dengan pandangan negatif, seperti: "Saya miskin, berasal dari keluarga pas-pasan, dan tidak mungkin punya kesempatan untuk sukses serta melakukan hal-hal menarik", hingga akhirnya muncul irrational belief yang menghambat pengembangan dirinya seperti "Kesempatan saya untuk berkembang pasti terbatas karena saya berasal dari keluarga yang pas-pasan."

Fenomena tersebut ternyata juga terjadi di SMK Negeri 31 yang berlokasi di Cempaka Putih, Jakarta Pusat. Dengan lokasi yang berada di daerah yang cukup pesat perkembangan ekonominya, siswa di sekolah ini terpapar dengan gaya hidup perkotaan. Mereka juga tidak luput dari arus informasi di media sosial yang sangat menekankan pentingnya penampilan, kepemilikan materi, gaya hidup trendy, dan sebagainya. Sementara itu, mayoritas siswa sekolah ini berasal dari keluarga dengan latar belakang sosial ekonomi menengah ke bawah. Kondisi ini diperkirakan turut mempengaruhi penilaian diri dan kepercayaan diri siswa secara umum. Banyak di antara siswa tersebut yang akhirnya melakukan penilaian diri yang salah, yakni "Saya berasal dari keluarga pas-pasan, jadi Saya tidak punya kesempatan untuk lebih sukses di masa depan" atau "Dengan kondisi keluarga saya saat ini, sudah bias bersekolah di SMK saja sudah beruntung, jadi tidak perlu 
bermimpi terlalu tinggi”. Akibatnya, tidak jarang siswa hanya menampilkan prestasi akademik minimal guna memenuhi standar kelulusan minimal.

Walaupun terlihat sederhana, masalah di atas akhirnya menimbulkan dampak terhadap prestasi siswa. Siswa yang seharusnya bias memperoleh prestasi akademik yang optimal justru hanya memperoleh pencapaian seadanya saja. Lebih jauh lagi, fenomena ini akan menimbulkan kesan bahwa siswa SMK memang tidak mampu berprestasi. Selain itu, kurangnya kepercayaan diri juga menjadi masalah bagi para siswa ketika hendak memasuki dunia kerja. Banyak di antaranya yang kurang mampu "menjual dirinya" saat menjalani proses wawancara kerja, sehingga mereka kalah dalam berkompetisi dengan kandidat karyawan dari sekolah lain. Lebih jauh lagi, banyak di antara mereka yang walaupun sudah bekerja, justru tidak mampu mengembangkan potensi dalam dirinya karena terjebak dengan irrational belief bahwa orang yang tidak mampu hanya dapat bekerja di level bawah, dan sulit untuk sukses.

Dengan adanya fenomena tersebut, penting bagi SMK Negeri 31 untuk mengadakan program konseling untuk meningkatkan kemampuan siswanya dalam menghargai diri sendiri (peningkatan self-esteem). Namun sayang, hingga saat ini pihak sekolah belum mempunyai sumber daya manusia yang mumpuni untuk merancang dan menjalankan program tersebut. Oleh karena itu, kami selaku dosen dari Fakultas Psikologi Universitas YARSI bermaksud mengajukan usulan program intervensi untuk meningkatkan kepercayaan diri siswa SMK 31.

\section{Tujuan Kegiatan}

Beberapa tujuan kegiatan yang akan dilakukan, adalah:

a. Membantu siswa SMK 31 untuk lebih dapat memahami dirinya, terutama gambaran mengenai potensi yang dimiliki.

b. Membantu siswa SMK 31 dalam mengembangkan kepercayaan dirinya agar lebih siap bersaing di dunia kerja.

c. Memberikan informasi kepada guru, terutama guru BK mengenai gambaran kepercayaan diri siswa dan cara untuk mengembangkannya.

\section{Manfaat Kegiatan}

Manfaat dari kegiatan ini adalah: 
a. Siswa SMK 31 yang terlibat dalam kegiatan akan lebih mengenali dirinya, terutama kelebihan ataupun kekurangan yang dimiliki.

b. Siswa SMK 31 yang terlibat dalam kegiatan ini, dapat mengetahui dan menerapkan cara-cara yang dapat dilakukan untuk mengembangkan kepercayaan diri.

c. Guru BK dapat memanfaatkan infomasi yang sudah diperoleh dari kegiatan yang diikuti untuk membantu memantau/mendampingi siswa peserta pelatihan agar lebih mengembangkan kepercayaan dirinya, atau membantu siswa lain yang mengalami malasah yang serupa.

\section{TINJAUAN PUSTAKA}

\section{Pengertian Self Esteem}

Pembahasan mengenai kepercayaan diri seringkali sulit dilepaskan dari konstruk dalam Psikologi, yaitu Konsep Diri (Self-Concept) dan Harga Diri (Selfesteem). Sebab, individu yang memiliki kepercayaan diri pasti diiringi pula oleh pemahaman yang jelas mengenai gambaran dirinya (konsep diri yang jelas), serta mampu menghargai berbagai kelebihan dan kekurangan dalam dirinya sebagai keunikan (harga diri yang positif). Namun sayangnya, masyarakat awam seringkali mencampuradukkan ketiga istilah tersebut seolah-olah memiliki persamaan arti. Harga diri berkaitan dengan konsep diri karena keduanya merupakan aspek dari sense of self yang saling berkaitan satu sama lain (Omrod, 2008; McDevitt \& Omrod, 2010). Sense of self sendiri memiliki definisi sebagai persepsi, keyakinan, penilaian, dan perasaan yang dimiliki seseorang terhadap siapa dirinya sebagai seorang manusia (Omrod, 2008; McDevitt \& Omrod, 2010). Walaupun konsep diri dan harga diri memang saling berkaitan satu sama lain, keduanya merupakan aspek yang berbeda dan memiliki pengertian masing-masing.

McDevitt dan Omrod (2010) menyebutkan bahwa konsep diri (self concept) berkaitan dengan pertanyaan "siapakah diri saya?" Konsep tersebut mencakup pengetahuan seseorang mengenai karakteristik diri, kelebihan, dan kekurangan yang dimiliknya. Kemudian, harga diri (self esteem berhubungan dengan pertanyaan, "seberapa baik diri saya?” Konsep tersebut meliputi penilaian terhadap 
nilai dan rasa keberhargaan diri seseorang, seperti pernyataan "saya merasa senang dengan bentuk tubuh saya yang proporsional.” Pintrich dan Schunk (dalam Eggen dan Kauchak, 2007) menjelaskan pula bahwa konsep diri merupakan penilaian kognitif (cognitive appraisal) terhadap keadaan fisik, sosial, serta pencapaian akademik seseorang. Sementara itu, harga diri merupakan reaksi emosional, ataupun penilaian terhadap diri sendiri oleh individu (Pintrich dan Schunk dalam Eggen dan Kauchak, 2007). Sebagai contoh, seorang remaja dapat menilai bahwa ia memiliki kemampuan inteligensi yang tinggi (konsep diri) dan merasa bahwa hal tersebut bernilai positif (harga diri).

Dalam praktek nyata, konsep diri sendiri sulit untuk dipisahkan dengan harga diri. Sebab, ketika manusia sudah memiliki informasi mengenai dirinya sendiri, secara otomatis ia akan melakukan penilaian positif ataupun negatif terhadap berbagai informasi dirinya tersebut. Sementara itu, individu tidak akan mampu memiliki harga diri yang positif sebelum ia berhasil mendeskripsikan dirinya (konsep diri) secara jelas dan akurat. Maka tidak heran jika berbagai tokoh seperti Branden (1994), Donchadha (2000), maupun Sherfield (2004) menjadikan konsep diri yang jelas sebagai bagian dari proses peningkatan harga diri (selfesteem) individu.

Sherfield (2004) menyebutkan bahwa seseorang dengan harga diri yang sehat mempunyai pandangan yang positif dan konstruktif terhadap dirinya. Dengan demikian, ia akan memiliki keyakinan terhadap kemampuannya sendiri, mampu menerima kelebihan dan keterbatasan dirinya, menetapkan tujuan yang realistis dan berusaha mencapainya, mampu mengembangkan hubungan yang positif dengan orang lain, serta dapat memperoleh kenyamanan hidup di lingkungan sekitarnya (Sherfield, 2004). Sementara itu, individu dengan harga diri yang rendah memiliki pandangan negatif dan pesimistik terhadap dirinya sendiri, serta ketidakmampuan untuk melihat keterbatasan dan masalah yang sedang dihadapi. Rendahnya harga diri sendiri sebenarnya merupakan salah satu masalah kesehatan mental karena dapat menyebabkan berkurangnya kemampuan individu dalam menetapkan sasaran, menurunkan motivasi, menghambat kemampuan dalam menjalin 
hubungan yang bermakna, serta membuat individu hanya terfokus pada kelemahan dalam dirinya saja (Sherfield, 2004).

Selanjutnya, penelitian yang dilakukan oleh Rossenberg dan Owens (dalam Guindon, 2010) menunjukkan bahwa individu yang mepunyai harga diri rendah memiliki beberapa karakteristik, yaitu: (1) Lebih sensitif terhadap pengalaman yang dapat mengancam maupun merendahkan harga dirinya, (2) Mudah terganggu oleh kritik, dan memiliki reaksi emosional besar terhadap kegagalan, (3) Membesarbesarkan suatu peristiwa sebagai hal yang negatif, dan menganggap komentar sebagai kritik, (4) Memiliki kecemasan dalam bersosialisasi, (5) Memiliki sensitivitas yang tinggi terhadap penilaian orang lain terhadap dirinya, (6) Kurang memiliki kepercayaan diri dalam membina hubungan interpersonal, (7) Merasa canggung, malu, dan segan untuk menjadi pusat perhatian, serta kurang mampu mengekspresikan dirinya ketika berinteraksi dengan orang lain, (8) Menghindarkan dirinya dari kegagalan, dan berusaha untuk tidak melakukan kesalahan, (9) Merasa hidupnya tidak bahagia, dan mudah mengalami tekanan emosional seperti depresi dan kecemasan, (10) Cenderung pesimistik, sinis, dan bersikap negatif terhadap institusi, kelompok, maupun orang lain, (11) Menunjukkan pemikiran yang tidak konstruktif, seperti sikap kaku dan tidak fleksibel, (12) Cenderung ragu-ragu dan lambat dalam memberikan respon ketika dirinya harus mengambil keputusan.

\section{Faktor-faktor yang Mempengaruhi Perkembangan Harga Diri}

Donnchadha (2000) menyebutkan bahwa harga diri merupakan sebuah proses dan bukan sebuah produk yang dapat diperoleh secara langsung. Harga diri merupakan proses yang terus berjalan semenjak individu masih kecil hingga tumbuh menjadi dewasa. Sherfield (2004) menyebutkan bahwa faktor yang umumnya dapat mempengaruhi perkembangan harga diri seseorang adalah keluarga (terutama orangtua), guru atau lingkungan sekolah, teman sebaya, serta pengaruh dari televisi, film, serta musik. Sementara itu, dalam penelitian yang dilakukan oleh Du Bois (dalam Ariyani, 2004) diketahui bahwa terdapat lima faktor yang berperan dalam pembentukan harga diri pada remaja, yaitu: faktor keluarga, teman sebaya, sekolah, kepuasan terhadap tubuh (body image), dan olahraga. 
Orangtua berperan dalam pembentukan harga diri melalui pemberian umpan balik terhadap setiap perilaku yang diperbuat oleh anak. Selain itu, orangtua juga memiliki andil yang besar dalam menetapkan standar baik dan buruk yang dijadikan sebagai patokan dalam evaluasi diri. Standar yang tidak realistis dapat menimbulkan masalah pada harga diri anak, misalnya: yang dikategorikan baik adalah nilai di atas 90, sehingga nilai 70 dianggap tidak baik. Hal demikian juga dapat terjadi di lingkungan sekolah, dimana perbandingan antar siswa yang dilakukan oleh guru dapat membuat anak yang dianggap "bodoh" akhirnya merasa rendah diri. Sementara itu, lingkungan teman sebaya sangat berperan dalam menetapkan standar penerimaan, seperti kriteria anak yang popular dan tidak popular. Anak yang tidak masuk dalam kriteria tersebut seringkali dianggap "culun", dikucilkan, dan akhirnya mengganggap dirinya tidak menarik. Lebih jauh lagi, media massa pun berperan dalam pembentukan harga diri melalui seloganselogan yang ditampilkan dalam berbagai acara. Sebagai contoh: orang yang cantic adalah yang berkulit putih, remaja yang "gaul" haruslah memiliki smartphone dengan kualitas kamera baik untuk selfie, dan sebagainya. Akibatnya, timbul persepsi di masyarakat bahwa standar tersebutlah yang menjadi patokan untuk mengevaluasi diri, dan mereka yang penampilannya tidak sesuai dengan selogan tersebut dapat merasa rendah diri.

\section{Strategi Peningkatan Harga Diri}

Seperti sudah dijelaskan sebelumnya, perkembangan harga diri seseorang sangat dipengaruhi oleh bagaimana lingkungan membentuk konsep mengenai mana yang baik dan mana yang buruk, serta bergantung pula terhadap umpan balik yang diberikan oleh berbagai pihak di sekitar individu. Hal tersebut akhirnya berdampak pada munculnya penyebab rendahnya harga diri, seperti kekaburan identitas (ketidakjelasan konsep diri), evaluasi yang salah terhadap konsep diri (irrational belief), perilaku yang justru memperburuk kondisi self-esteem seseorang, hingga pergaulan yang berdampak negatif terhadap harga diri seseorang. Dengan bervariasinya faktor penyebab rendahnya harga diri seseorang, program intervensi yang diberikan juga harus disesuaikan dengan faktor penyebab tersebut. 
Guindon (2010) mengelompokkan berbagai strategi intervensi tersebut dalam lima kategori, yaitu: (1) pemberian dukungan sosial, (2) strategi kognitif behavioral, (3) strategi konseling individual, keluarga, dan kelompok, (4) strategi peningkatan kebugaran fisik, dan (5) strategi spesifik lainnya. Setiap strategi memiliki kelebihan dan kekurangannya masing-masing, dan penggunaannya perlu disesuaikan dengan karakteristik klien yang akan menjalani intervensi. Misalnya saja, pemberian dukungan sosial akan lebih tepat ditujukan bagi individu yang memiliki lingkungan pergaulan yang negative (selalu merendahkan diri individu), atau strategi kognitif behavioral lebih tepat diberikan bagi individu yang mempunyai keyakinan yang salah (irrational belief) mengenai gambaran dirinya sendiri.

Tokoh lain bernama Borba (1989) juga berkomentar bahwa untuk mengatasi permasalahan harga diri, kita harus menelaah lebih dalam mengenai faktor pembentuk dari harga diri individu. Menurut Borba (1989), harga diri terdiri atas berbagai komponen, mulai dari kepercayaan terhadap orang lain (Security), pengetahuan yang ia miliki terhadap dirinya sendiri (Selfhood), gambaran mengenai hubungannya dengan orang lain (Affiliation), tanggung jawab, dan tujuan hidup yang dimiliki individu dalam hidupnya (mission), serta gambaran tentang kesuksesan yang diperolehnya di masa lalu (Competence). Gambaran yang individu miliki terhadap lima komponen tersebut-lah yang akhirnya membentuk harga diri (Borba, 1989). Oleh karena itu, program intervensi sebaiknya dikembangkan berdasarkan kelima komponen tersebut (Borba, 1989).

\section{METODE}

Sasaran dari kegiatan ini adalah 50 siswa kelas XI SMK 31 Jakarta, yang sudah ditunjuk oleh guru BK dari jurusan Akuntansi, Perkantoran dan Pemasaran. Akan tetapi, pada hari pelaksanaannya, peserta kegiatan yang mengikuti proses pelatihan secara lengkap hanya berjumlah 36 orang. Bentuk intervensi yang dilakukan adalah dengan memberikan penyuluhan untuk mengembangkan dimensi-dimensi self efteem. Kegiatan pertama adalah refleksi diri dengan mengisi kuesioner/alat ukur mengidentifikasi gambaran self esteem 
masing-masing peserta. Setelah itu, peserta akan mendapatkan penjelasan mengenai definisi self esteem, pentingnya self esteem yang baik, cara meningkatkan self esteem, dan lain sebagainya. Penjelasan dilakukan dengan metode yang menarik seperti dengan menampilkan cuplikan video, studi kasus, sharing pengalaman, games dan sebagainya. Setelah mendapatkan penjelasan, peserta diminta untuk melakukan refleksi diri kembali dan diskusi dengan peserta lainnya mengenai gambaran dirinya.

Metode yang diterapkan untuk mengukur efektivitas pelatihan adalah dengan membandingkan pengetahuan peserta mengenai minat saat pre-test dan post test, sebagaimana tergambar pada gambar 3.

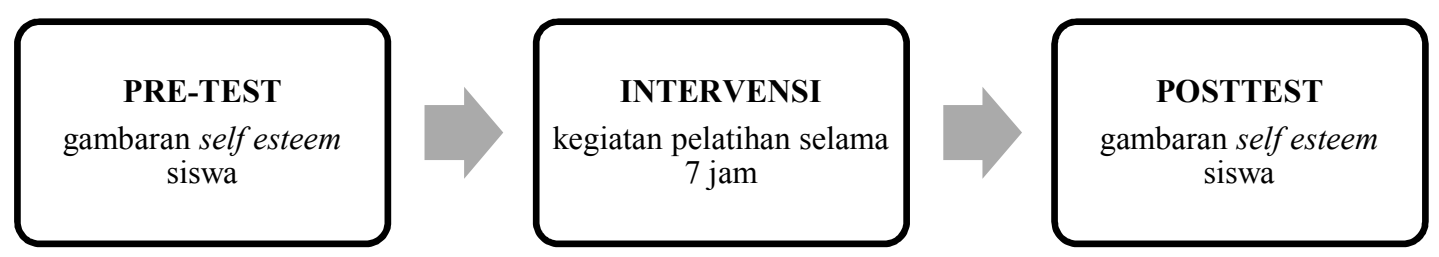

Gambar 1: Bagan pengukuran efektivitas pelatihan

Evaluasi yang akan dilakukan terkait dengan:

a. Evaluasi dilakukan untuk melihat efektivitas kegiatan yang dilakukan, terutama untuk mengukur perubahan aspek kognitif (pengetahuan) peserta. Evaluasi dilakukan sebanyak dua kali, yaitu pada saat sebelum kegiatan dan setelah kegiatan. Kegiatan dikatakan efektif apabila terdapat perbedaan signifikan antara skor pengetahuan sebelum dan setelah mengikuti kegiatan.

b. Evaluasi pelaksanaan kegiatan pengabdian masyarakat. Evaluasi ini bertujuan untuk mengetahui manfaat kegiatan yang dilakukan dan masukan/ saran terkait pelaksanaan kegiatan. Evaluasi ini hanya dilakukan satu kali pengambilan data, yaitu pada akhir kegiatan.

\section{HASIL DAN PEMBAHASAN}

\section{Gambaran Hasil Kegiatan}

Seperti sudah disebutkan pada bagian sebelumnya, tujuan dari pelatihan pengembangan Self-Esteem ini adalah untuk meningkatkan kemampuan siswa 
SMK 31 untuk memahami potensi dalam dirinya, sekaligus agar mereka lebih mampu mengembangkan kepercayaan diri. Oleh karena itu, peserta diajak untuk menelaah secara lebih mendalam mengenai deskripsi dirinya secara fisik, pengalaman unik yang mereka miliki, minat dan kegemaran, serta kelebihan dan kekurangan yang mereka miliki. Pada setiap sesinya, peserta akan dijelaskan terlebih dahulu mengenai pentingnya pengenalan setiap aspek tersebut, serta langkah-langkah yang dapat dilakukan untuk mengetahuinya. Setelah itu, barulah peserta diminta untuk mengisi lembar kerja yang bersifat self-report. Dengan penggunaan istilah "Pelatihan", maka kegiatan ini mencakup $50 \%$ penyampaian materi dan $50 \%$ praktek langsung. Yang dimaksud dengan praktek langsung di sini yaitu peserta diminta secara langsung untuk mengisi lembar kerja yang bertujuan untuk melakukan analisa diri, mulai dari secara fisik, pengalaman unik, minat dan kegemaran, hingga kelebihan dan kekurangan. Oleh karena itu, untuk dapat mengetahui tingkat keberhasilan pelatihan, dilakukan penilaian melalui dua cara, yakni dengan menggunakan pre-test dan post-test, serta melihat performa peserta dalam mengisi lembar kerja individual.

Untuk pre-test dan post-test itu sendiri, tim dosen memberikan sebuah kuesioner yang terdiri dari 30 item. Kuesioner ini dikembangkan oleh Borba (1989), dan sudah diterjemahkan ke dalam Bahasa Indonesia oleh Brebahama (2012). Secara umum, kuesioner ini mengukur sejauh mana peserta menunjukkan indikator perilaku yang terkait dengan kepemilikan harga diri yang positif. Skala yang digunakan dalam kuesioner tersebut merupakan skala likert, yang dimulai dari (1) tidak pernah, (2) jarang, (3) sering, hingga (4) selalu. Dari skala tersebut, dapat diketahui bahwa nilai minimum yang dapat dipeoleh peserta adalah 30, dan nilai maksimum yang dapat diperoleh peserta adalah 120. Kategorisasi tinggi dan rendahnya self-esteem dilakukan dengan berpatokan pada nilai tengah, yaitu 75. Dengan demikian, peserta yang memperoleh skor kuesioner lebih rendah dari 75 dikatakan memiliki tingkat self-esteem yang rendah. Sementara, peserta yang memperoleh skor lebih tinggi dari 75 dikatakan memiliki self-esteem yang tinggi. 
Seperti sudah disebutkan pada bagian sebelumnya, untuk mengetahui apakah terdapat perubahan setelah dilakukan pelatihan, maka tim dosen menggunakan teknik statistic T-test untuk melakukan uji beda antara skor posttest dengan skor pre-test. Berikut ini merupakan hasil dari uji statistic tersebut, yaitu:

Tabel 1. Hasil Uji Beda antara Skor Pre-Test dengan Skor Post-Test

\section{T-Test}

[DataSet0]

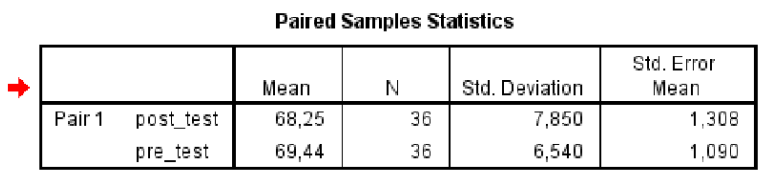

Paired Samples Correlations
\begin{tabular}{|lc|r|r|r|}
\hline & \multicolumn{1}{|c|}{$N$} & Correlation & Sig. \\
\hline Pair 1 post_test \& pre_test & 36 &, 830 &, 000 \\
\hline
\end{tabular}

\begin{tabular}{|c|c|c|c|c|c|c|c|c|c|}
\hline \multicolumn{10}{|c|}{ Paired Samples Test } \\
\hline & & \multicolumn{5}{|c|}{ Paired Differences } & \multirow[b]{3}{*}{$t$} & \multirow[b]{3}{*}{ df } & \multirow[b]{3}{*}{ Sig. (2-tailed) } \\
\hline & & \multirow[b]{2}{*}{ Mean } & \multirow[b]{2}{*}{ Std. Deviation } & \multirow{2}{*}{$\begin{array}{l}\text { Std. Error } \\
\text { Mean }\end{array}$} & \multicolumn{2}{|c|}{$\begin{array}{l}95 \% \text { Confidence Interval of the } \\
\text { Difference }\end{array}$} & & & \\
\hline & & & & & Lower & Upper & & & \\
\hline Pair 1 & post_test - pre_test & $-1,194$ & 4,381 & 730 & $-2,677$ & .288 & $-1,636$ & 35 & 111 \\
\hline
\end{tabular}

Berdasarkan tabel 1, dapat dilihat bahwa skor rata-rata (mean) antara pre-test dan post test tidak memiliki perbedaan yang signifikan (mean skor pretest $=68,25$, mean skor post-test $=69,44)$. Hal ini semakin diperkuat dengan melihat signifikansi uji T-Test yang ternyata lebih besar daripada 0,05 , yaitu 0,111 . Dengan demikian, dapat disimpulkan bahwa memang tidak terdapat perbedaan signifikan antara skor post-test jika dibandingkan dengan skor pretest. Untuk lebih detil, tim dosen berusaha melihat apakah terdapat peningkatan jumlah siswa yang memiliki self-esteem lebih tinggi saat post-test. Hasilnya dapat dilihat pada tabel 2 berikut ini.

Tabel 2. Hasil Pengolahan Data Pre-test dan Post-test

\begin{tabular}{|c|c|c|c|c|c|}
\hline \multicolumn{6}{|c|}{ Pretest } \\
\hline & & Frequency & Percent & Valid Percent & $\begin{array}{c}\text { Cumulative } \\
\text { Percent }\end{array}$ \\
\hline \multirow[t]{3}{*}{ Valid } & rendah & 32 & 88,9 & 88,9 & 88,9 \\
\hline & tinggi & 4 & 11,1 & 11,1 & 100,0 \\
\hline & Total & 36 & 100,0 & 100,0 & \\
\hline
\end{tabular}

posttest

\begin{tabular}{|l|r|r|r|r|}
\hline & Frequency & Percent & Valid Percent & $\begin{array}{c}\text { Cumulative } \\
\text { Percent }\end{array}$ \\
\hline Valid rendah & 33 & 91,7 & 91,7 & 91,7 \\
\hline
\end{tabular}


Berdasarkan tabel 2. dapat dilihat bahwa belum terdapat perubahan yang signifikan dalam hal jumlah peserta yang memiliki gambaran diri yang positif. Pada saat sesi pre-test, terdapat 34 siswa yang memiliki harga diri yang rendah (low selfesteem). Sementara itu, pada sesi post-test, masih terdapat 33 orang peserta yang harga dirinya tergolong rendah. Artinya, hanya terdapat satu orang yang mengalami peningkatan self-esteem setelah mengikuti pelatihan ini.

Ada beberapa hal yang perlu diperhatikan dalam menyikapi hasil pre-test dan post-test tersebut. Alat ukur yang digunakan merupakan kuesioner yang mengukur aspek afektif dan perilaku, dan bukan mengukur pemahaman materi oleh peserta. Sementara itu, untuk dapat mengubah aspek afektif dan perilaku, dibutuhkan waktu yang lebih panjang (tidak cukup hanya satu hari pelatihan). Hal ini diperkuat oleh pernyataan Borba (1989) bahwa harga diri sangat dipengaruhi oleh lingkungan dimana seorang individu berada, dan biasanya berkembang dalam waktu yang cukup lama. Donchadha (2000) juga mengutarakan bahwa self-esteem dibentuk melalui proses yang cukup lama, mulai dari ketika anak masih diasuh oleh orangtua, saat sang anak berada di sekolah, ketika anak berinteraksi dengan teman sebaya, hingga akhirnya ia tumbuh dewasa. Dengan demikian, self-esteem siswa yang rendah akibat bentukan dari lingkungan tentunya tidak dapat diubah hanya dalam satu hari kegiatan, namun dibutuhkan proses yang berkelanjutan dengan melibatkan guru sekolah.

Selanjutnya, jika memperhatikan performa peserta dalam mengisi lembar kerja, terlihat bahwa 36 peserta mampu menyelesaikan lembar kerja yang terdiri dari:

\section{Lembar kerja Deskripsi Diri}

36 siswa mampu mendeskripsikan diri mereka secara fisik. Di akhir sesi pertama, mereka lebih memahami bahwa kriteria fisik akan berujung pada keunikan diri mereka, dan tidak hanya mengacu pada baik/buruk. Mereka lebih mampu melihat ciri fisik terkait dengan modal dasar dalam bekerja, seperti mata yang sehat sebagai modal dasar dalam bekerja.

2. Lembar Kerja Kenangan Hidup 
36 siswa tersebut lebih mampu menyebutkan berbagai pengalaman hidup mereka secara umum, dan tidak hanya terfokus pada pengalaman buruk dalam hidup mereka. Pada akhir sesi ini, siswa lebih mampu melihat bahwa setiap orang pasti akan mengalami pengalaman yang positif dan negatif secara silih berganti.

3. Lembar Kerja Minat dan Kegemaran

36 siswa mampu menyebutkan berbagai hobi dan kegemaran mereka yang unik, sehingga mereka tidak hanya terfokus pada nilai akademik di sekolah.

4. Lembar Kerja Kelebihan dan Kekurangan

36 siswa mampu mengidentifikasi kelebihan dan kekurangan diri mereka berdasarkan ciri fisik, pengalaman hidup, hobi dan kegemaran, termasuk juga aspek akademik. Hal ini membantu mereka lebih realistis dalam memilih pekerjaan di masa mendatang.

5. Lembar Kerja Biodataku

Pada akhir sesi ini, seluruh siswa sudah mampu menuliskan biodata mereka secara objektif. Biodata ini nantinya akan menjadi modal dasar dalam penulisan CV ketika mereka akan memasuki dunia kerja.

\section{Efektivitas Kegiatan}

Berdasarkan pengolahan data secara statistik, dapat disimpulkan bahwa pelatihan peningkatan self-esteem belum dapat meningkatkan self-esteem siswa secara efektif. Namun, jika memperhatikan performa siswa secara kualitatif, dapat dilihat bahwa secara kognitif, pelatihan ini mampu meningkatkan pemahaman siswa mengenai aspek-aspek yang mempengaruhi pembentukan self-esteem mereka. Pelatihan ini juga mampu meningkatkan pemahaman siswa terhadap strategi untuk meningkatkan self-esteem yang mereka miliki.

\section{Evaluasi Pelaksanaan Kegiatan}

Selain melakukan pemberian pre-test dan post-test, kami juga meminta peserta untuk mengisi lembar evaluasi kegiatan untuk mengukur sejauh mana keberhasilan pelaksanaan pelatihan ini. Secara umum, evaluasi mencakup empat aspek, yaitu: manfaat pelatihan, metode kegiatan, kejelasan materi, dan sikap fasilitator pelatihan terhadap peserta. Peserta diminta untuk memberikan pendapat 
dengan rentang 4 skala, mulai dari tidak memuaskan, kurang memuaskan, baik, dan sangat baik. Apabila dikonversi dalam bentuk angka, rentang penilaian tersebut berkisar dari angka 1 hingga angka 4. Berdasarkan hasil pengolahan statistik terhadap 36 lembar evaluasi peserta, diketahui bahwa keempat aspek penilaian memiliki rata-rata peniliaian di atas 3 , atau berada pada kategori baik. Hal ini menunjukkan bahwa seluruh peserta memiliki evaluasi yang positif terhadap keempat aspek kegiatan. Hanya saja, perlu dilakukan penelaahan secara lebih spesifik mengenai penilaian peserta terhadap setiap aspek, seperti yang tercantum pada bagan 3 di bawah ini.

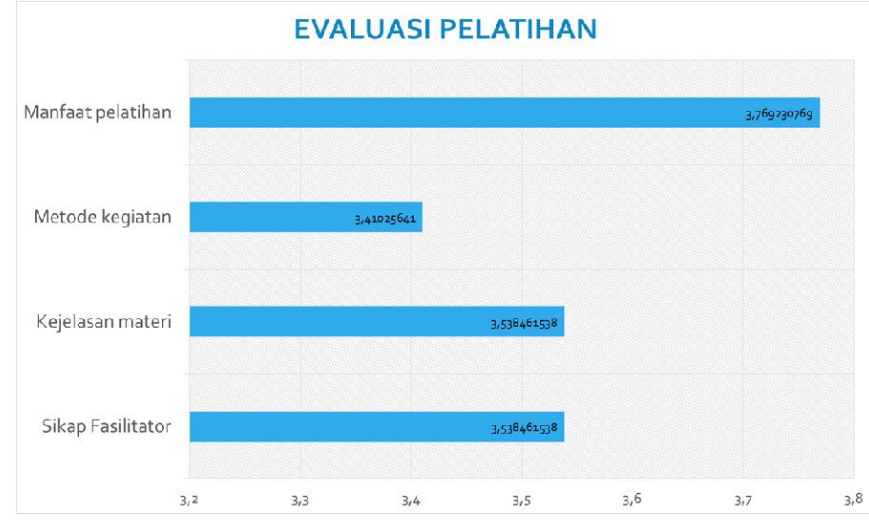

Berdasarkan bagan di atas, dapat dilihat bahwa seluruh peserta memberikan evaluasi yang baik terhadap keempat aspek pelatihan. Hanya saja, dari keempat aspek tersebut, aspek manfaat pelatihan berada pada kategori penilaian paling baik, yaitu 3,76. Hal ini dikkarenakan peserta jarang sekali mengikuti pelatihan yang berorientasi pada pengembangan diri. Selama ini, mereka lebih banyak mengikuti kegiatan yang berfokus pada pengembangan keterampilan (hard skill) yang sejalan dengan latar belakang pendidikan SMK yang mereka jalani. Sementara itu, mata pelajaran Bimbingan dan Konseling belum dapat mengakomodir pelaksanaan kegiatan serupa karena adanya keterbatasan jumlah jam pelajaran jika dibandingkan dengan padatnya materi BK, serta keterbatasan jumlah SDM jika dibandingkan dengan jumlah siswa yang perlu ditangani.

Selanjutnya, aspek sikap fasilitator dan kejelasan materi pelatihan memiliki rentang penilaian yang hampir sama, yaitu 3.53. Walaupun penilaian terhadap aspek ini berada di bawah aspek manfaat kegiatan, keduanya masih berada dalam 
kategori baik. Materi dianggap cukup jelas karena tim penyusun mengembangkan kegiatan ini berdasarkan teori Self Esteem dari Michelle Borba yang sebelumnya sudah pernah diuji coba di Amerika Serikat dengan melibatkan banyak siswa sekolah menengah. Selain itu, penyusunan modul juga dilakukan dengan menyesuaikan karakteristik siswa SMK yang cenderung lebih terbiasa berpikir konkret. Seluruh materi ditampilkan secara visual dengan bantuan tayangan visual, diiringi dengan penjelasan secara lisan, serta pemberian lembar kerja yang sejalan dengan pemaparan materi. Sementara itu, peserta memberikan penilaian positif terhadap fasilitator karena keempat pemateri (Alabanyo Brebahama, Sari Zakiah Akmal, Octaviani Indrasari, dan Rina Rahmatika) merupakan psikolog yang terbiasa untuk menghadapi klien dengan beragam sifat dan karakter. Hal ini membuat pemateri mampu berempati ketika peserta mengalami kesulitan, sehingga penyampaian materi tidak hanya bersifat satu arah, namun memberikan ruang bagi peserta untuk bertanya.

Selanjutnya, aspek metode kegiatan berada pada peringkat keempat jika dibandingkan dengan keempat aspek lainnya. Secara umum, peserta cukup antusias dengan adanya selingan ice breaking dan permainan dalam kegiatan pelatihan ini. Mereka pun bersemangat dalam menyimak materi maupun mengisi lembar kerja yang diberikan. Hanya saja, pelaksanaan kegiatan di hari Sabtu menjadi catatan khusus karena hari ini merupakan waktu libur bagi siswa SMKI 31. Selain itu, kegiatan yang dipadatkan dalam satu hari selama enam jam dinilai cukup berat bagi peserta. Hal ini tentunya menjadi masukan bagi pelaksanaan kegiatan selanjutnya.

\section{KESIMPULAN DAN SARAN}

\section{Kesimpulan}

Berdasarkan hasil pelaksanaan dan evaluasi kegiatan pengabdian masyarakat yang berjudul "Pelatihan Pengembangan Self-Esteem bagi siswa SMK Negeri 31" dapat disimpulkan bahwa:

a. Kegiatan pelatihan ini memang belum dapat meningkatkan Self-Esteem siswa SMK Negeri 31 Jakarta secara langsung. Namun, melalui kegiatan ini, secara kognitif siswa sudah lebih mampu memahami pengertian konsep

Fakultas Psikologi, Universitas Muhammadiyah Jember | 25 
diri (Self-Concept) dan harga diri (Self-Esteem), serta memahami hal-hal yang dapat membangun harga diri mereka.

b. Program pelatihan ini memperoleh evaluasi yang positif dari peserta, terutama pada aspek manfaat pelatihan. Walaupun peserta belum mengalami peningkatan Self-Esteem secara langsung, namun mereka memperoleh manfaat yang besar dari materi yang disampaikan, maupun lembar kerja yang diberikan kepada mereka.

\section{Saran}

Beberapa saran yang dapat diberikan sebagai masukan untuk kegiatan Pelatihan Peningkatan self-esteem berikutnya adalah:

a. Pelaksana kegiatan perlu menggunakan soal pre-test dan post-test yang mengukur tingkat pengetahuan dan pemahaman peserta mengenai materi pelatihan, sehingga dapat melihat perkembangan pada aspek kognitif peserta.

b. Pelaksana kegiatan selanjutnya perlu melakukan sasu sesi follow up kurang lebih 3 bulan setelah dilaksanakannya kegiatan, sehingga dapat melihat perubahan afektif dan perilaku peserta terkait dengan harga diri (selfesteem) yang mereka miliki.

c. Pelatihan selanjutnya perlu melibatkan guru Bimbingan dan Konseling dalam melakukan sesi follow up. Guru sekolah juga perlu diajarkan untuk dapat memberikan umpan balik yang objektif kepada siswa guna membentuk self-esteem yang lebih positif.

\section{DAFTAR PUSTAKA}

Ariyani, A. (2004). Perbedaan Hope dan Self-Esteem antara Remaja yang Pernah Menggunakan Narkoba dan Remaja yang Tidak Pernah Menggunakan Narkoba. Tugas Akhir, tidak diterbitkan. Depok: Universitas Indonesia.

Borba, M. (1989). Esteem Builder (Self Esteem Curriculum for Improving Student Achievement, Behavior, and School Climate). New York; Jalmar Press 
Branden, Nataniel. (1994). Six Pillars of Self Esteem (The Definitive Work on SelfEsteem \by the Leading Pioneer in the Field). New York; Random, Inc

Carr-Gregg, M. \& Shale, E. (2003). Adolescence (A Guide for Parents). London; Vemilion, an Imprint of Ebury Press Random House UK, Ltd

Donnchadha, Rammon. (2000). The Confident Child. Dublin; New Leaf, an Imprint of Gill \& Macmillan, Ltd

Eggen, P. \& Kauchak, D. (2007). Educatonal Psychology - Windows on Classroom ( $7^{\text {th }}$ edition). New Jersey; Pearson Prentice Hall

Guindon, M.H. (2010). Self Esteem Across The Lifespan. New York : Routledge Taylor \& Francis Group.

Mc-Devitt, T. M. \& Ormrod, J. E. (2010). Child Development and Education $4^{\text {th }}$ edition. New Jersey: Pearson Education, Inc.

Papalia, D.E., Olds, S.W., \& Feldman, R.D. (2007). Human Development $10^{\text {th }}$ ed. USA: McGraw-Hill Companies, Inc.

Sherfield, R. M. (2004). The Every Thing Self Esteem Book; Boost Your Confidence, Achieve Inner Strength, and Learn to Love Yourself. Avon; F+W Publications, Inc 